\title{
A reliable and non-destructive method for estimating forage shrub cover and biomass in arid environments using digital vegetation charting technique
}

\author{
Mounir Louhaichi · Sawsan Hassan · Kathryn Clifton • Douglas E. Johnson
}

Received: 20 August 2015/ Accepted: 21 February 2017/Published online: 27 February 2017

(C) The Author(s) 2017. This article is published with open access at Springerlink.com

\begin{abstract}
Despite the importance of fodder shrubs to small ruminant diets and production in arid and semiarid ecosystems, they are often not considered when quantifying grazing land potential. This oversight is mainly due to the time consuming and costly traditional techniques used to estimate shrub biomass. The shrub fodder component should be measured to avoid underestimation of the carrying capacity of rangelands. In this study, we present a fast, reliable and non-destructive method to estimate canopy vegetation cover to obtain aboveground shrub biomass. The experiment was conducted under field conditions in northwest Syria, where seedlings of seven shrub species were monitored for one year: Atriplex leucoclada (Moq.) Boiss., A. halimus L., A. lentiformis (Torr.) S. Watson, A. canescens (Pursh) Nutt., A. nummularia Lindl., Salsola vermiculata L. and Haloxylon aphyllum (C.A. Meyer) Bunge. The experimental layout was a randomized complete block design with five replications. We explored the effectiveness of digital vegetation charting technique (DVCT) for estimating shrub canopy cover.
\end{abstract}

M. Louhaichi $(\bowtie) \cdot S$. Hassan · K. Clifton

Social, Economic and Policy Research Program (SEPRP), International Center for Agricultural Research in Dry Areas (ICARDA), P.O. Box 950764, Amman 11195, Jordan

e-mail:m.louhaichi@cgiar.org

M. Louhaichi · D. E. Johnson

Department of Animal and Rangeland Sciences, Oregon

State University, Corvallis, OR 97331, USA
Aboveground shrub biomass was clipped to estimate the dry matter (DM) weight per species and to determine its relationship to canopy cover. In this study, an estimate of greenness (percent green vegetation cover) was extracted by way of greenness algorithms. Simple linear regressions between vegetation cover and biomass for 210 plots were performed. The cover of the seven species differed $(P<0.01)$ : A. leucoclada had the highest vegetation cover $(56 \%)$ and $H$. aphyllum the lowest $(7 \%)$. Vegetation cover and DM biomass were positively correlated $(P<0.01)$ with R-squared ranging from 0.66 (H. aphyllum) to 0.84 (S. vermiculata). Our method provided reasonable estimations of canopy coverage which could predict aboveground phytomass. We conclude that DVCT offers a rapid, reliable and consistent measurement of shrub cover and biomass provided that shrubs have open architecture. This study shows the potential of digital cameras and image processing to determine cover/biomass in a nondestructive, timely and cost efficient way.

Keywords Rangelands - Vegetation cover - Remote sensing $\cdot$ Halophytes $\cdot$ VegMeasure $\cdot$ Image processing

\section{Introduction}

Shrubs play a significant, worldwide role in human endeavors, and many indigenous people rely heavily on them for their livelihoods. In many arid and semi- 
arid ecosystems, fodder shrubs are vital for small ruminant production and particularly goats. Their major value is that they provide protein, vitamins and frequently mineral elements, which are lacking in grassland pastures during the dry season (Le Houérou 1980; Breman and De Ridder 1991; Breman and Kessler 1995; Ahamefule et al. 2006). Despite their importance, they are often not considered when quantifying grazing land potential. This oversight is mainly due to the time consuming and costly traditional techniques used to estimate shrub biomass. The shrub fodder component should be measured to avoid underestimation of the carrying capacity of rangelands.

Researchers have developed methods for measuring vegetation changes that are cost effective, reliable and repeatable (Stoddard and Smith 1943; Floyd and Anderson 1987; Brady et al. 1995; Brakenhielm and Liu 1995; Seefeldt and Booth 2006). Traditional methods involve using quadrats to analyze plant cover, density and aboveground biomass (Cooper 1924; Barbour et al. 1987; Magill 1989; Cox et al. 1990; Hill et al. 2005; Hoover 2008; Louhaichi et al. 2009; Gayton 2014).

Shrub biomass can be estimated using direct (destructive) or indirect (non-destructive) techniques. The most accurate method for estimating biomass is by destructive sampling-clipping and weighing the grazable portion in the field (Gibbs et al. 2007; Chojnacky and Milton 2008). Costs and logistics associated with field measurements always limit the number of destructive samples, the number of shrubs harvested, the parts of the shrub measured and the size of shrubs harvested (Clark et al. 2001). In addition, destructive techniques prevent repeated measures over time with the same plant, leading to increased variability between observations. To avoid total plant harvest, a semi-destructive shrub biomass estimation technique was developed using representative samples or 'reference units', which reduced the need to clip the entire grazable biomass for each shrub. Use of reference units increases the number of shrubs that can be sampled, allowing monitoring to capture the variability of shrubland (Andrew et al. 1981).

As an alternative to destructive techniques, shrub biomass can be estimated using variables that are correlated with it, such as rainfall. Thus, in the 1980s there were several attempts to develop regressions between seasonal rainfall and biomass at peak standing crop. In most cases, the response to rainfall increases positively with the total amount per season (Le Houérou and Hoste 1977; Deshmukh 1984). Unfortunately, this relationship works best with herbaceous strata and not with other life forms such as shrubs. With a similar aim, shrub biomass equations were developed as a function of shrub dimensions such as diameter and height. Equations were usually developed for particular species, and most generated equations were for temperate coniferous forest types (Cannell 1984). Shrub size biomass relationships can be established per species; however, shrubs have to be destroyed and regression formulas created (Ludwig et al. 1975; Chojnacky and Milton 2008). Once this is completed and the relationship has been established, future destruction would be limited.

Vegetation canopy cover is another variable used as a non-destructive surrogate for biomass estimates (Montes et al. 2000; Sala and Austin 2000). In fact, canopy cover is an important ecological characteristic and is generally calculated as the percentage of ground surface covered by vegetation. Cover can be expressed in absolute terms $\left(\mathrm{m}^{2} / \mathrm{ha}\right)$ but is most often expressed simply as a percentage. Visual plant cover estimates are often used because they are more rapid, much easier and, therefore, cheaper to measure (Sykes et al. 1983). In particular, the line-intercept method (Canfield 1941; Gayton 2014; Montalvo et al. 2014), which records the length of canopy overlap along a stretched tape laid out on the ground, has been widely used in grasslands and steppes.

With the recent advances in geo-spatial technologies, remote sensing (RS) techniques have been used at a much broader scale to estimate shrub biomass (Franklin and Hiernaux 1991; Roy and Ravan 1996; $\mathrm{Lu}$ 2006). In fact, satellite imagery is a common tool to generate monitoring and forage prediction maps (AlBakri and Taylor 2003; Frank and Karn 2003; Kawamura et al. 2005). However, broad-scale satellite images are often too course or have inaccuracies in semi-arid and arid areas (Smith et al. 1990). Highresolution satellite RS imagery, as well as aerial photography (Sivanpillai and Booth 2008) and unmanned air vehicles (Rango et al. 2009; Zhang and Kovacs 2012), have been used for fine-scale mapping but are often restricted by the higher cost and security concerns (Anderson and Gaston 2013). Landsat imagery with $30 \mathrm{~m}$ spatial resolution has difficulty estimating vegetation cover that is less than 
$40 \%$ and has limited use in measuring variations in semi-arid and arid environments (Smith et al. 1990). Abdullah et al. (2011) reported that physical measurements of phytomass of different plant types/ species at ground reference sites are necessary for biomass estimation using high-resolution satellite imagery.

More recently, digital cameras have been shown to be fast, affordable and reliable for measuring biomass and Leaf Area Index (Casadesús and Villegas 2014). There are a number of software packages capable of measuring cover and bare ground from an image (Lamari 2002; Louhaichi et al. 2010). Digital images can be classified and interpolated to give overall cover maps for the site of interest. The digital vegetative charting technique (DVCT) uses digital cameras in a standardized manner to classify and measure vegetation on the ground and requires specialized software to process digital images. VegMeasure ${ }^{\circledR}$ is software that processes images that are collected in a standardized manner to provide classification of imagery and measure changes over time (Louhaichi et al. 2010). Variability in the estimates from DVCT was less than the variability of estimates across personnel who collected data using traditional methods (Booth et al. 2005). DVCT also provided greater accuracy than visual estimates (Olmstead et al. 2004). The fine-scale information provided through high-resolution detailed imagery at local scale when coupled with large-scale satellite RS can be used as reference data or training sites to produce detailed classification maps that have greater detail and accuracy than could be provided from low resolution remote sensing alone.

Remote sensing techniques employ regression/correlation of the canopy area recorded by the sensor against the biomass measured directly or estimated indirectly on the ground. For instance, vegetation indices convert reflectance, and sometimes shrub size and roughness, to biomass based on statistical relationships established by destructive sampling (Bar Massada et al. 2006). By transforming remote sensing data into index values, researchers can generate surrogate information that give a rough measure of vegetation type, amount and condition on land surfaces (Jensen 2007; Lillesand et al. 2008). Remote sensing imagery, such as the Normalized Difference Vegetation Index (Tucker 1978; Steven et al. 2003), that show overall greenness are commonly used in monitoring and to provide predictions and estimates of plant biomass (Tucker et al. 1983; Sannier et al. 2002; Kawamura et al. 2005; Mata et al. 2007). Unfortunately, most algorithms and regressions relating remote sensing data to biomass are site and date specific or difficult to transfer to other locations due to the limitations of the model itself, and often contain substantial standard errors (Lu 2006). Therefore, it is important to make simultaneous ground measurements to increase the accuracy of remotely sensed data.

This study tested the measurement of shrub canopy cover of multiple species through DVCT. We also investigated the relationship between canopy cover and biomass production of seven shrub species commonly used for rehabilitation of degraded rangelands in arid environments using simple linear regression. Such information could contribute to the incorporation of biomass estimates for shrubs and be potentially useful for the incorporation of shrubs in the REDD + (Reducing emissions from deforestation and forest degradation) carbon payment scheme.

\section{Materials and methods}

Study site

The field experiment was conducted at the International Center for Agricultural Research in the Dry Areas (ICARDA Tel Hadya station) located in Aleppo in northwest Syria $\left(36^{\circ} 1^{\prime} 15.61^{\prime \prime} \mathrm{N}, 36^{\circ} 57^{\prime} 20.23^{\prime \prime} \mathrm{E}\right.$; $300 \mathrm{~m}$ above sea level). The soil at the station is generally deep (over $1 \mathrm{~m}$ ) and has a heavy clay texture (fine clay, montmorillonitic, thermic Calcixerollic Xerochrept). pH 8.0; $\mathrm{CaCO}_{3} 240 \mathrm{~g} \mathrm{~kg}^{-1}$ organic matter $8.4 \mathrm{~g} \mathrm{~kg}^{-1}$. The soil saturated hydraulic conductivity is moderate to low rate (Ryan et al. 1997). The climate of the site is cool semi-arid Mediterranean with an average annual rainfall of $340 \mathrm{~mm}$ and the growing season during October-May. During the study period which lasted from the 18th of November 2009 to the 28th of April 2010, the total amount of rainfall received was $327.1 \mathrm{~mm}$ in 2009 and $129.2 \mathrm{~mm}$ in 2010 .

Target shrub species

A total of seven halophyte shrub species important for rangeland rehabilitation and livestock feeding in the 
arid Mediterranean basin and Central Asia (Winter 1981; Le Houérou 1992a) were tested in the current study: Atriplex leucoclada (Moq.) Boiss., A. halimus L., A. lentiformis (Torr.) S. Watson, A. canescens (Pursh) Nutt., A. nummularia Lindl., Salsola vermiculata L. and H. aphyllum (C.A. Meyer). More detailed description of these species is presented below:

Atriplex leucoclada, an important rangeland plant species. It grows in arid and semi-arid areas. It is drought resistant and halophytic, tolerating soil salinity levels as high as $30 \mathrm{dS} / \mathrm{m}$ (Al-Oudat and Qadir 2011). The plant exhibits high forage value qualities and provides part of animal requirements, especially in autumn and winter for all livestock classes. Atriplex leucoclada has been shown to readily establish from seed (Le Houérou 1996) enhancing restoration efforts.

Atriplex halimus is a perennial native shrub of the Mediterranean basin with an excellent tolerance to drought, salinity, and alkaline soils. It is known for its remediation of degraded rangelands and salt-affected areas. It is used as a phytoremediation plant in highly saline sodic clay loam soils. Atriplex Halimus grows well with high evapotranspiration and low mean annual precipitation of $100-400 \mathrm{~mm}$ and $400-600$ $\mathrm{mm}$ for arid and semi-arid areas respectively (Walker et al. 2014). Optimal soil textures for growth include silty, loamy, and clayey soils whereas coarse sandy and heavy clay soils produce poor results and should be avoided completely (Le Houérou 2010).

Atriplex lentiformis grows well under saline-sodic soils with heavy clay textures (Le Houérou 2010). Atriplex lentiformis is an erect medium sized Atriplex plant with silvery-green leaves and a well-developed root system that can reach water tables down to $10 \mathrm{~m}$ depth (Le Houérou 1992b).

Atriplex canescens is adapted to semiarid conditions (Garza and Fulbright 1988). It can grow on deep, halophytic, sandy soils with 150 and $400 \mathrm{~mm}$ annual rainfall. Salty soil salts improve growth of $A$. canescens by improving organic matter production, water use efficiency, and increasing the ability to extract water through osmotic adjustments (Glenn and Brown 1998).

Atriplex nummularia is used as a forage crop in arid and semi-arid areas due to its high palatability compared to other Atriplex species, but is prone to over-browsing and may fail to re-grow. Atriplex nummularia grows in arid and semi-arid areas with 150-400 mm mean annual precipitation and tolerates moderate drought. The roots of nummularia can go as deep as $10 \mathrm{~m}$ reaching a deep-lying water table (Le Houérou 1992b, 2010). Medium textured soils are most suitable for cultivation and sandy soils should be avoided completely (Le Houérou 1992b).

Salsola vermiculata is a perennial shrub and perhaps the most valuable browse species in arid rangelands of WANA. Typical of dry soils under arid climates (Rivas-Martínez et al. 2001). It grows in sandy or clay soils with variable salinity, above tide level, and is frequent along roadsides, abandoned crop fields, rocky slopes, disturbed sites and maritime habitats (Reyes-Betancort et al. 2001).

Haloxylon aphyllum is an important perennial plant in Asia. It tolerates arid and semi-arid conditions with less than $200 \mathrm{~mm}$ annual rainfall (Arabzadeh and Emadian 2010). It grows in topographic depressions on sandy, solonchak, or gypsum soils (Gintzburger et al. 2003). The plant is widely used to rehabilitate degraded rangelands (Shamsutdinov and Shamsutdinov 2008).

\section{Experimental design}

Seeds of selected shrub species were germinated in pots in a greenhouse. The pots were filled with a mixture of $1 / 3$ soil, $1 / 3$ sand, and $1 / 3$ of organic manure (applied as a top layer). The resulting soil was alkaline with a pH of 8.4; an organic matter content of $0.29 \%$. Once the seedlings reached maturity stage, the pots were placed outside to mimic natural field conditions. Contiguous research plots $(2 \mathrm{~m} \times 2 \mathrm{~m})$ were prepared by cultivation. The shrub seedlings were transplanted into the center of its assigned $2 \mathrm{~m} \times 2 \mathrm{~m}$ area in the field in March using a randomized complete block design (RCBD) with five replications. A total of 210 seedlings were planted, six of each species in each of the five replicates. Plants were then monitored for canopy cover and biomass production over the duration of the experiment.

\section{Monitoring techniques}

To test the efficacy of digital photography for ground cover estimations, straight down images from 1.5 to $6 \mathrm{~m}$ above the ground were obtained using a highresolution digital camera following the DVCT protocols (Louhaichi et al. 2010). The digital camera used in this study was a Samsung Techwin (model 
NV100HD, VLUU NV100HD, LANDIAO NV100 HD, TL34HD) equipped with a $28-\mathrm{mm}$ lens. The dimensions of each image were $4384 \times 3288$ pixels and the size was about $3434 \mathrm{~kb}$ in JPG format. On three occasions after transplanting (at day 296, 406 and 458) photos were taken from both $1.5 \mathrm{~m}$ above the ground (Fig. 1a) for individual shrubs and from $6 \mathrm{~m}$ (Fig. 2a) to provide a lower resolution (ground pixel size of about $3 \mathrm{~mm}$ ) assessment of cover for a relative comparison within the subplot. At peak standing crop, the aboveground shrub biomass was clipped at $5 \mathrm{~cm}$ height, dried for $24 \mathrm{~h}$ at $70{ }^{\circ} \mathrm{C}$ and weighed to estimate the dry matter (DM) weight per species.

Estimates of greenness (\% green vegetation cover) were calculated from the digital camera images using supervised classification technique in VegMeasure software $^{\circledR}$ (Louhaichi et al. 2001; Johnson et al. 2009). VegMeasure is a DVCT that measures vegetation on the ground in a non-destructive manner. The colors from the digital camera can be interpreted by the software to create meaningful classes. This technique allows customization of the images. In this study we only had two categories: plant or canopy cover and soil or bareground. After uploading the images to a specific folder, few images were selected to set the threshold for each class and act as training sites for the performing image processing. The pixels for each category in the image having the same value would be displayed with a distinct color. At any time the user can display results in progress by clicking on Statistics option. This step allows the user to know what percentage falls in each class and how many pixels remains unclassified. Once the thresholds are set we run the program for patch processing of all the images stored in the designated folder. This process would generate an output folder containing the processed images and a summary excel file that illustrate the name of each image and the values (\%) of the classification for each category. The total surface area of green vegetation from the image classification is calculated by summing the total area occupied by pixels classified as plant. This total surface area (\%) was then regressed against the DM biomass clipping weights to assess the relationship of green cover in the images versus standing biomass. Once the image processing is complete, the program computes the accuracy assessment. This is done through computing the error matrix and the Kappa Index of Agreement. This latter is commonly used in remote sensing classification to assess the degree of success of a classification technique. The error matrix permits measurement of overall accuracy, category accuracy, producer's accuracy and user's accuracy (Congalton 1991).

\section{Statistical analysis}

Changes in plant cover were modeled by fitting a generalized linear model using binomial error and logit link function for each of the three times of plant cover observed. To evaluate the main effects of species on plant cover, data were analyzed using a repeated measures model in randomized complete blocks. Biomass data were analyzed as a RCBD using analysis of variance (ANOVA). Univariate regression analyses were used to examine relationships between biomass (as the dependent variables) and plant cover using the last observation date. Univariate regression is described as follows:

$$
\mathrm{y}=\alpha+\beta \mathrm{x}
$$
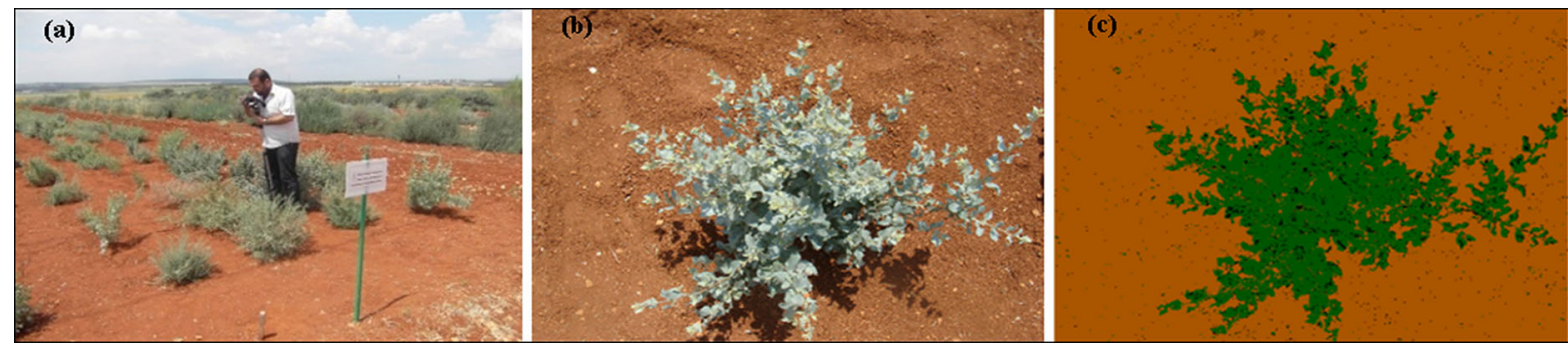

Fig. 1 Estimation of shrub canopy cover using a digital camera mounted on a monopod $1.5 \mathrm{~m}$ above the ground: a image collection with the equipment, $\mathbf{b}$ natural image of a shrub plant on the ground and $\mathbf{c}$ extracted image of the canopy coverage from the digital image using image processing VegMeasure program 

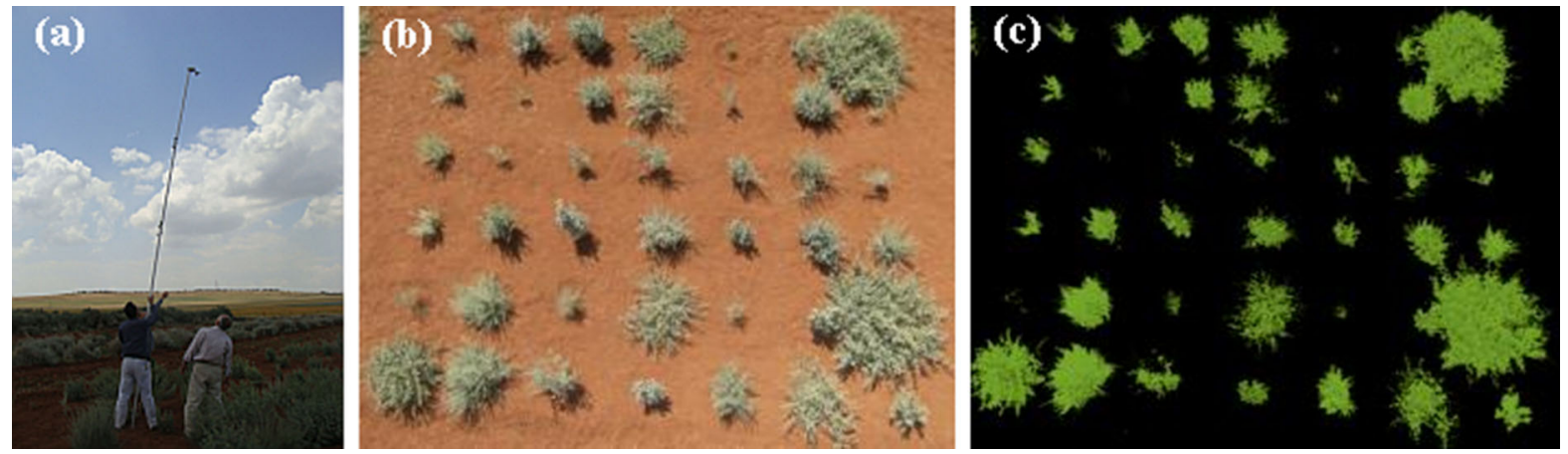

Fig. 2 Estimation of shrub canopy cover using a digital camera mounted on a monopod $6 \mathrm{~m}$ above the ground: a image collection with the equipment, $\mathbf{b}$ natural image of the shrub

where $\mathrm{y}$ is dependent variable; $\mathrm{x}$ is independent variable; $\alpha$ is the intercept and $\beta$ is slope of this function. The intercept was set to 0 in our calculated models as it is more reasonable. Therefore, the resulting model implies that biomass should be 0 when plant cover is 0 . When a significance value is not given in the text, results were not significant at $P<0.05$. This model opted to be used because it fits the trends in our dataset better than logarithmic and exponential regressions in terms of R-squared value. While parabolic regression does not provides that significant improvement to justify using more complex models. All statistical analyses were carried out using Genstat software (Payne 2014). The latest version of VegMeasure has a built-in tool 'Assess Accuracy' for assessing accuracy (Johnson et al. 2015), which allows easy computation of an error matrix and a Kappa Index of Agreement for the processed pictures.

\section{Results}

Atriplex leucoclada had the highest evolution of average vegetation cover over time followed by $A$. halimus, while $H$. aphyllum had the lowest $(P<0$. 01). Atriplex leucoclada plant cover increased from $5.16 \%$ (296 days after transplanting) to $56 \%$ (406 days after transplanting). Similarly, S. vermiculata, A. lentiformis, A. canescens and A. nummularia had the same trend of average vegetation cover over time. Salsola vermiculata plant cover ranged from 1.9, 3.70 and $18.23 \%$ in 296, 406 and 458 days after pots transplanting respectively. Likewise A. lentiformis community on the ground and $\mathbf{c}$ extracted image of the canopy coverage of the shrub community from the digital image using image processing VegMeasure program

vegetation cover changed from $2 \%$ in 296 days after transplanting to $17.76 \%$ in 406 days after transplanting (Fig. 3). Among all the seven shrub species $H$. aphyllum performed the lowest plant cover changed from 0.37 to $3.61 \%$ in 296 days and 406 days after transplanting respectively (Fig. 3).

Data on biomass showed strong heterogeneity of error variances; however, the square-root transformed values supported the assumptions of consistency of error variances and normality of experimental errors. Species differences in biomass were significant $(P<0.001$, Table 1$)$. Among the shrub species evaluated, A. leucoclada had the greatest biomass $(775 \mathrm{~g}$ $\mathrm{DM} / \mathrm{shrub}$ ) followed by A. halimus (366 g DM/shrub) and $S$. vermiculata (228.5 g DM/shrub), while $H$. aphyllum had the lowest (25.9 g DM/shrub). However, there was no significant difference in biomass yield among A. lentiformis, A. canescens and A. nummularia. The study was set up in a manner that the effect of climate would be uniform and data is cross comparable. Therefore, climate differences were not a factor as planting and sampling were conducted on the same dates and the duration of the study was relatively short. As indicated earlier, the soil conditions and the rainfall pattern during the study period were not limiting factors to inhibit growth of the selected species. In general these species would withstand much drier and harsh conditions and that is why they are recommended for rehabilitation of degraded rangelands.

The slopes derived from the linear regression for the plant cover (\%) of each species were positively correlated with biomass, with $\mathrm{R}$-squared $\left(\mathrm{R}^{2}\right)$ ranging from 0.66 ( $H$. aphyllum) to 0.84 (S. vermiculata), 


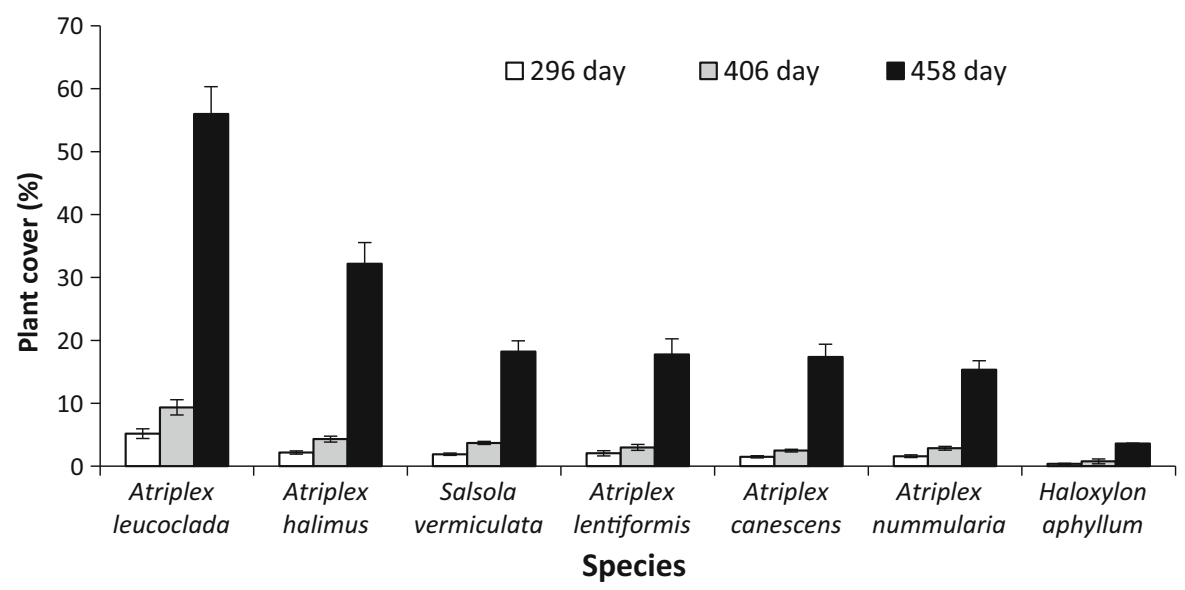

Fig. 3 Canopy cover evaluation over time (296, 406 and 458 days after seeding) of seven halophytes estimated with DVCT for monitoring shrub canopy cover

Table 1 Mean aboveground biomass (g) for single plants of different shrub species

\begin{tabular}{ll}
\hline Species & Mean biomass \\
\hline A. leucoclada & $774.9^{\mathrm{a}}$ \\
A. halimus & $366.1^{\mathrm{b}}$ \\
S. vermiculata & $228.5^{\mathrm{c}}$ \\
A. lentiformis & $155.7^{\mathrm{d}}$ \\
A. canescens & $149.8^{\mathrm{d}}$ \\
A. nummularia & $134.4^{\mathrm{d}}$ \\
H. aphyllum & $25.9^{\mathrm{e}}$
\end{tabular}

${ }^{1}$ Numbers followed by different letters are significantly different $(P<0.05)$; shrub biomass values were subject to square-root transformations in ANOVA

differing significantly for all species $(P<0.01$, Table 2). In our models we referred the range of validity upon the scope of plant cover observed in the study for each species, for $H$. aphyllum this model is correct when the plant cover is $10 \%$ or less (Table 2).
Furthermore, results show that image processing to estimate vegetation cover using supervised classification provide the best overall classification accuracies at approximately $97 \%$. This accuracy is higher than running the build in green leaf algorithm.

\section{Discussion}

Although it is highly unlikely an estimation technique will meet every desirable trait, they should include a combination of accuracy, speed, precision, limited interference from environmental conditions and topography, and if instruments are required, they should be inexpensive and easy to operate (Tucker 1980). The use of vegetation cover as a surrogate variable for shrub biomass has the advantage of being non-destructive and faster compared to the harvest technique (Flombaum and Sala 2007; Tarhouni et al. 2016). A continuous need for economical and accurate
Table 2 Simple linear regression parameters assuming intercept is 0 to model the relationship between the biomass ( $\mathrm{g}$ / shrub) and DVCTestimated plant cover (\%) of seven halophytes

\begin{tabular}{lrllc}
\hline Species & $\beta$ & $\mathrm{R}^{2}$ & $\begin{array}{l}\text { Model } \\
P \text { value }\end{array}$ & $\begin{array}{l}\text { Range of observed } \\
\text { plant cover (\%) }\end{array}$ \\
\hline A. leucoclada & 14.68 & 0.809 & $<0.001$ & $15-95$ \\
A. halimus & 11.68 & 0.828 & $<0.001$ & $5-75$ \\
S. vermiculata & 12.89 & 0.843 & $<0.001$ & $0-40$ \\
A. lentiformis & 9.14 & 0.750 & $<0.001$ & $0-50$ \\
A. canescens & 7.74 & 0.744 & $<0.001$ & $0-45$ \\
A. nummularia & 8.13 & 0.740 & $<0.001$ & $5-35$ \\
H. aphyllum & 6.97 & 0.658 & $<0.001$ & $0-10$ \\
\hline
\end{tabular}


measurements of shrub biomass that can be repeated with precision has led to the progressive development of the DVCT. Thus, biomass can be estimated over time in the same location to assess temporal response patterns. Such monitoring would assist researchers and ecologists in future assessments to better understand and test hypotheses about change or stability of ecosystems. Changes in shrub density and size would be easily detected. Digital records can be kept permanently to observe trends over long periods.

DVCT has primarily been used in rangelands to monitor and measure changes over time and to evaluate the effectiveness of restoration (Louhaichi et al. 2013) and managerial techniques. For example, DVCT was used to monitor impact of herbicide on native forbs in the sagebrush/bunchgrass steppe (Louhaichi et al. 2012). DVCT applications have been proven to be a successful method for agronomic researches in particular to estimate the ground cover of the monocultures (Preuss et al. 2012). This current study confirmed that the DVCT technique is valuable and reliable for estimating forage cover and biomass of young shrubs. DVCT method provided a reasonable estimation of canopy coverage for the shrub species that were tested in the current study. A positive relationship between vegetation cover and DM biomass with $\mathrm{R}^{2}$ of $0.658-0.843$ was found.

Shrub size is important for rehabilitation projects because larger individuals generally produce more fodder for livestock and wildlife, more seed and improve the soil seed bank ( $\mathrm{Li}$ et al. 2014). The combination of vertical photography from a fixed height and digital image analysis allowed us to scale images so that either percent cover or horizontal surface area as $\mathrm{m}^{2}$ per plant could be calculated. In our experiment, shrubs were well spaced and had high contrast with the soil color (Figs. 1b, c, 2b,c), so confusion or overlap between species or individuals was not an issue. Our imagery provided a quick and quantitative estimate of horizontal shrub size which could be combined with a measurement of shrub height taken in the field with a meter stick.

It is worth to mention that while cover can be used as a proxy to estimate biomass, it does have limitations in terms of general accuracy especially with globular or compact shrubs. Therefore, researchers should create regression equations for each shrub species and each plant community. Biomass estimation for shrub species with an erect architecture (upright vertical habit) may be underestimated; while shrub cover of species with open or horizontal growth are, most likely, more accurate. Combining other variables, such as height or vertical shape, could improve the accuracy of biomass estimates.

For meaningful interpretation, shrub data must be converted from biomass per plant to biomass per unit area, requiring additional estimates of shrub density. Vertical images taken from high altitude allow researchers to calculate both shrub density and cover. Because natural shrublands are composed of shrub species at various ages and growth stages, a series of images taken at random locations could be used to estimate density, cover and aboveground biomass. Shrubs could also be grouped into size classes. In any case, a set of properly collected and dated, geographically registered, digital images contain a wealth of information about the shrubland ecosystem.

The effect of rainfall on arid and semi-arid rangeland vegetation has been well documented showing a positive correlation (Le Houérou and Hoste 1977). The growth habit (life form) and plant size are factors that affect plant cover as well as biomass production or net primary productivity (NPP) (Flombaum and Sala 2007; Hamada et al. 2011; Hernández et al. 2011). In fact the influence of species traits on NPP has been studied empirically in a number of cases (Saugier et al. 2001; Williams et al. 2005; Kerkhoff et al. 2006; Byrne et al. 2011). During the study period the rainfall was adequate and met the requirements of the studied shrub species.

Among the shrub species A. leucoclada had the highest plant cover. This can be explained by the fact that this shrub is mealy-canescent prostrate to erect stems, 30-100 cm. Furthermore, A. leucoclada had the highest biomass of the seven shrub species-it is a shrub-like biennial that requires only two years to complete its full life-cycle (Sankary 1986). The other shrubs, which are more widely spread throughout the Syrian steppe, are perennial and require more time for establishment and growth. A. lentiformis, A. nиттиlaria and $A$. canescens are erect medium sized Atriplex plants while S. vermiculata is a small, greyish, much-branched shrub ranging in height from 25 to $100 \mathrm{~cm}$. On the other hand, H. aphyllum is perennial shrub or small $100-800 \mathrm{~cm}$ tall, many erect to pendant branches. H. aphyllum had the lowest plant cover this could be due the slow growth in the first year of establishment compared to the other species. 
Accuracy assessment of vegetation cover derived from remote sensing data has been documented as a valuable tool in evaluating the fitness of these data for estimating biomass production (Congalton 1991). Accuracy assessment mostly generates one single measure such as proportion of pixels correctly classified. The contrast encountered between the color of soil and vegetation cover was so distinct. This factor facilitated the image processing which led to a high overall accuracy. Other factors which should be considered for reaching remarkable results include resolution of the digital camera. In this regards the camera should be set on the finest resolution possible. Timing during the day also may interfere with the quality of the output. In general, it is recommended to avoid early and late afternoon. Also make sure there is no shadow in the ground where the image will be taken (Johnson et al. 2015).

\section{Conclusion}

Various techniques have been developed to take indirect measurements of biomass, including modifying previous methods, developing different measurements and creating new tools for measurements. It is difficult to explicitly declare one method superior to another, because each was developed for a specific need; consequently, each method has strengths and weaknesses in certain situations. The ability to quickly measure shrub cover to determine biomass has global implications. Understanding shrub cover/biomass relations on drylands is a valuable tool to monitor conservation, rehabilitation and improved management. DVCT was a robust and cost effective method for estimating cover and aboveground biomass of shrubs in in our arid ecosystem. We suggest that this technique can provide quantitative information to aid understanding of shrub ecosystem dynamics, change in the shrub carbon pool and identify climate change mitigation opportunities. It could facilitate smallholder farmers' ability to verify improvement and capitalize on the emerging green economy.

Digital imagery collection can speed up data collection over larger areas, lowering the cost of monitoring while reducing destruction of shrub species. Our study identified relationships between DVCT-measured shrub cover and biomass for seven species and found acceptable estimates useful for managerial decisions for six shrubs $\left(\mathrm{R}^{2}>0.85\right)$. These equations permit aboveground biomass estimation from digital image analysis without the need for vegetative destruction, providing a quick and cost efficient way to estimate carrying capacity for livestock and wildlife as well as to monitor shrubland condition and trend on a larger scale.

Acknowledgements The authors acknowledge ICARDA, the CGIAR Research Program on Livestock Agri-Food Systems (CRP Livestock) and Oregon State University (OSU), Department of Animal and Rangeland Sciences for their support and funding. Special thanks go to Dr. Jay Angerer (Texas A \& M University) for his critical review of this manuscript.

Open Access This article is distributed under the terms of the Creative Commons Attribution 4.0 International License (http:// creativecommons.org/licenses/by/4.0/), which permits unrestricted use, distribution, and reproduction in any medium, provided you give appropriate credit to the original author(s) and the source, provide a link to the Creative Commons license, and indicate if changes were made.

\section{References}

Abdullah HM, Akiyama T, Shibayama M, Awaya Y (2011) Estimation and validation of biomass of a mountainous agroecosystem by means of sampling, spectral data and QuickBird satellite image. Int J Sustain Dev World Ecol 18:384-392

Ahamefule FO, Obua BE, Ibeawuchi JA, Udosen NR (2006) The nutritive value of some plants browsed by cattle in Umudike, Southeastern Nigeria. Pak J Nutr 5(5):404-409

Al-Bakri JT, Taylor JC (2003) Application of NOAA AVHRR for monitoring vegetation conditions and biomass in Jordan. J Arid Environ 54:579-593

Al-Oudat M, Qadir M (2011) The halophytic flora of Syria. International Center for Agricultural Research in the Dry Areas, Aleppo

Anderson K, Gaston KH (2013) Lightweight unmanned aerial vehicles will revolutionize spatial ecology. Front Ecol Environ 11:138-146

Andrew MH, Noble IR, Lange RT, Johnson AW (1981) The measurement of shrub forage weight: three methods compared. Rangel J 3:74-82

Arabzadeh N, Emadian SF (2010) Effect of water (drought) stress on water relations of Haloxylon aphyllum and $H$. persicum. Iran J Sci Technol Trans A Sci 34(A3):245-255

Bar Massada A, Carmel Y, Tzur GE, Grünzweig JM, Yakir D (2006) Assessment of temporal changes in aboveground forest tree biomass using aerial photographs and allometric equations. Can J Forest Res 36:2585-2594

Barbour MG, Burk JH, Pitts WD (1987) Terrestrial plant ecology. Benjamin/Cummings Publishing Company, Mento Park 
Booth DT, Cox SE, Johnson DE (2005) Detection-threshold calibration and other factors influencing digital measurements of ground cover. Rangel Ecol Manag 58(6):598-604

Brady WW, Mitchell JE, Bonham CD, Cook JW (1995) Assessing the power of the point-line transect to monitor changes in plant basal cover. J Range Manag 87:187-190

Brakenhielm S, Liu QH (1995) Comparison of field methods in vegetation monitoring. Water Air Soil Pollut 79:75-87

Breman H, De Ridder N (1991) Manuel sur les Pâturages des Pays Sahéliens. Karthala, Paris

Breman H, Kessler JJ (1995) Woody plants in agro-ecosystems of semiarid regions with emphasis on the Sahelian countries. Advanced series in agricultural sciences, vol 23. Springer, Berlin

Byrne KM, Lauenroth WK, Adler PB, Byrne CM (2011) Estimating aboveground net primary production in grasslands: a comparison of nondestructive methods. Rangel Ecol Manag 64:498-505

Canfield RH (1941) Application of the line interception method in sampling range vegetation. J For 39(4):388-394

Cannell MGR (1984) Woody biomass of forest stands. For Ecol Manag 8:299-312

Casadesús J, Villegas D (2014) Conventional digital cameras as a tool for assessing leaf area index and biomass for cereal breeding. J Integr Plant Biol 56:7-14

Chojnacky DC, Milton M (2008) Measuring carbon in shrubs. In: Hoover CM (ed) Field measurements for forest carbon monitoring. Springer, New York, pp 45-72

Clark DA, Brown S, Kicklighter DW, Chambers JQ, Thomlinson JR, Ni J (2001) Measuring net primary production in forests: concepts and field methods. Ecol Appl 11(2):356-370

Congalton RG (1991) A review of assessing the accuracy of classification of remotely sensed data. Remote Sens Environ 37:35-46

Cooper WS (1924) An apparatus for photographic recording of quadrats. J Ecol 12:317-321

Cox JR, Ruyle GB, Roundy BA (1990) Lehmann lovegrass in southeastern Arizona: biomass production and disappearance. J Range Manag 43:367-372

Deshmukh IK (1984) A common relationship between precipitation and Grassland peak biomass for East and Southern Africa. Afr J Ecol 22:181-186

Flombaum P, Sala OE (2007) A non-destructive and rapid method to estimate biomass and aboveground net primary production in arid environments. $\mathrm{J}$ Arid Environ 69:352-358

Floyd DA, Anderson JE (1987) A comparison of three methods for estimating plant cover. J Ecol 75(1):221-228

Frank AB, Karn JF (2003) Vegetation indices, $\mathrm{CO}_{2}$ flux, and biomass for northern plains grasslands. J Range Manag $56: 382-387$

Franklin J, Hiernaux HY (1991) Estimating foliage and woody biomass in Sahelian and Sudanian woodlands using a remote sensing model. Int J Remote Sens 12:1387-1404

Garza A Jr, Fulbright TE (1988) Comparative chemical composition of armed saltbush and fourwing saltbush. J Range Manag 41:401-403

Gayton D (2014) Grassland and forest understory vegetation monitoring: an introduction to field methods. J Ecosyst Manag 14(3) http://jem.forrex.org/index.php/jem/article/ viewFile/173/494. Accessed 14 Aug 2015
Gibbs HK, Brown S, Niles JO, Foley JA (2007) Monitoring and estimating tropical forest carbon stocks: making REDD a reality. Environ Res Lett 2(4):1-13

Gintzburger G, Toderich KN, Mardonov BK, Makhmudov MM (2003) Rangelands of the arid and semiarid zones in Uzbekistan. CIRAD, Montpellier

Glenn EP, Brown JJ (1998) Effects of salt levels on the growth and water use efficiency of Atriplex canescens (Chenopodicaceae) varieties in drying soil. Am J Bot 85:10-16

Hamada Y, Stow DA, Roberts DA (2011) Estimating life-form cover factions in California sage scrub communities using multispectral remote sensing. Remote Sens Environ 115(12):3056-3068

Hernández L, Laundré JW, González-Romero A, López-Portillo J, Grajales YKM (2011) Tale of two metrics: density and biomass in a desert rodent community. J Mammal 92:840-851

Hill MJ, Braaten R, Lees B, Veitch SM, Sharma S (2005) Multicriteria decision analysis in spatial decision support: the ASSESS analytic hierarchy process and the role of quantitative methods and spatially explicit analysis. Environ Model Softw 20:955-976

Hoover CM (2008) Field measurements for forest carbon monitoring: a landscape-scale approach. Springer, New York

Jensen JR (2007) Remote sensing of the environment: an earth resources perspective. Prentice Hall Inc., Upper Saddle River

Johnson MD, Louhaichi M, Woerz AL, Clark PE, Johnson DE (2009) VegMeasure 2 User's Manual. Department of Rangeland Ecology \& Management, Oregon State University. Corvallis, Oregon

Johnson MD, Louhaichi M, Johnson DE, Pearson A (2015) VegMeasure 2. Version 2.2. International Center for Agricultural Research in Dry Areas (ICARDA), Amman, Jordan. http://www.vegmeasure.org/download/252/. Accessed 25 May 2016

Kawamura K, Akiyama T, Yokota H, Tsutsumi M, Yasuda T, Watanabe O, Wang G, Wang S (2005) Monitoring of forage conditions with MODIS imagery in the Xilingol steppe, Inner Mongolia. Int J Remote Sens 26:14231436

Kerkhoff AJ, Brian J, Enquist JB (2006) Ecosystem allometry: the scaling of nutrient stocks and primary productivity across plant communities. Ecol Lett 9:419-427

Lamari L (2002) Assess: image analysis software for plant disease quantification. The American Phytopathological Society Press, St. Paul

Le Houérou HN (1980) Chemical composition and nutritive value of browse in tropical West Africa. In: Le Houérou $\mathrm{HN}$ (ed) Browse in Africa: the current state of knowledge. International Livestock Center for Africa, Addis Ababa, pp 55-82

Le Houérou HN (1992a) An overview of vegetation and land degradation in world arid lands. In: Dregne HE (ed) Degradation and restoration of arid lands. International Center for Arid and Semi-Arid Lands Studies (ICASALS), Texas Tech University, Lubbock, Texas, pp 127-163

Le Houérou HN (1992b) The role of saltbushes (Atriplex spp.) in arid land rehabilitation in the Mediterranean Basin: a review. Agrofor Syst 18(2):107-148 
Le Houérou HN (1996) Use of fodder trees and shrubs (trubs) in the arid and semi-arid zones of West Asia and North Africa: history and perspectives. In: Gintzburger G, Bounejmate M, Nefzaoui A (eds) Fodder shrub development in arid and semiarid zones. International Center for Agricultural Research in the Dry Areas, Aleppo, pp 9-53

Le Houérou HN (2010) Utilization of fodder trees and shrubs in the arid and semiarid zones of West Asia and North Africa. Arid Soil Res Rehabil 14:101-135

Le Houérou HN, Hoste CH (1977) Rangeland production and annual rainfall relations in the Mediterranean basin and in the African Sahelo-Sudanian zone. J Range Manag 30:163-178

Li X, Jiang D, Zhou Q, Oshida T (2014) Soil seed bank characteristics beneath an age sequence of Caragana microphylla shrubs in the Horqin sandy land region of northeastern China. Land Degrad Dev 25(3):236-243

Lillesand T, Kiefer RW, Chipman J (2008) Remote sensing and image interpretation. Wiley, Toronto

Louhaichi M, Borman MM, Johnson DE (2001) Spatially located platform and aerial photography for documentation of grazing impacts on wheat. Geocarto Int 16:63-68

Louhaichi M, Salkini AK, Petersen SL (2009) Effect of small ruminant grazing on the plant community characteristics of semiarid Mediterranean ecosystems. Int J Agric Biol 11:681-689

Louhaichi M, Johnson MD, Woerz AL, Jasra AW, Johnson DE (2010) Digital charting technique for monitoring rangeland vegetation cover at local scale. Int J Agric Biol 12:406-410

Louhaichi M, Carpinelli MF, Richman LM, Johnson DE (2012) Native forb response to sulfometuron methyl on medusahead-invaded rangeland in Eastern Oregon. Rangel $\mathbf{J}$ 34(1):47-53

Louhaichi M, Pyke DA, Shaff SE, Johnson DE (2013) Monitoring restoration Impacts to endemic plant communities in soil inclusions of arid environments. Int $\mathrm{J}$ Agric Biol 15:767-771

Lu DS (2006) The potential and challenge of remote sensingbased biomass estimation. Int $\mathrm{J}$ Remote Sens 27:1297-1328

Ludwig JA, Reynolds JF, Whitson PD (1975) Size-biomass relationships of several Chihuahuan desert shrubs. Am Midl Nat 94:451-461

Magill AW (1989) Monitoring environmental change with color slides. General Technical Report. PSW-117. Berkeley, California http://www.fs.fed.us/psw/publications/documents/ psw_gtr117/psw_gtr117a.pdf. Accessed 25 May 2016

Mata M, Clark DA, Edirisinghe A, Waugh D, Minneé E, Gherardi SG (2007) Predicting accurate paddock average pasture cover in Waikato dairy farms using satellite images. Proc NZ Grassl Assoc 69:23-28

Montalvo AE, JrD Ransom, Lopez RR (2014) Modeling greater roadrunners' (Geococcyx californianus) habitat use in West Texas. Wilson J Ornithol 126(2):359-366

Montes N, Gauquelin T, Badri W, Bertaudiere V, Zaoui EH (2000) A non-destructive method for estimating aboveground forest biomass in threatened woodlands. For Ecol Manag 130:37-46

Olmstead MA, Wample R, Greene S, Tarara J (2004) Nondestructive measurement of vegetative cover using digital image analysis. HortScience 39(1):55-59
Payne RW (2014) The guide to GenStat ${ }^{\circledR}$ release 17. Part 2: Statistics. VSN International, Hemel Hempstead, United Kingdom

Preuss CP, Louhaichi M, Huang CY, Ogbonnaya FC (2012) Genetic variation in the early vigor of twenty elite spring wheat under phosphate stress as characterized through digital charting. Field Crops Res 127:71-78

Rango A, Laliberte A, Herrick JE, Winters C, Havstad K, Steele C, Browning D (2009) Unmanned aerial vehicle-based remote sensing for rangeland assessment, monitoring, and management. J Appl Remote Sens 3:033542

Reyes-Betancort JA, Wildpret W, León Arencibia MC (2001) The vegetation of Lanzarote (Canary Islands). Phytocoenologia 31(2001):185-247

Rivas-Martínez S, Fernández-González F, Loidi J, Lousã M, Penas A (2001) Syntaxonomical checklist of vascular plant communities of Spain and Portugal to association level. Itinera Geobot 14(2001):5-341

Roy P, Ravan S (1996) Biomass estimation using satellite remote sensing data: an investigation on possible approaches for natural forest. J Biosci 21:535-561

Ryan J, Masri S, Garabet S, Diekmann J, Habib H (1997) Soils of ICARDA's agricultural experiment stations and sites: climate, classification, physical and chemical properties, and land use. Technical Bulletin, International Center for Agricultural Research in the Dry Areas (ICARDA), Aleppo, Syria

Sala OE, Austin AT (2000) Methods of estimating aboveground net primary productivity. In: Sala OE, Jackson RB, Mooney HA, Howarth R (eds) Methods in ecosystem science. Springer, New York, pp 31-43

Sankary MN (1986) Species distribution and growth in salt effected land of Syria. Reclam Reveg Res 5:125-143

Sannier CAD, Taylor JC, Du Plessis W (2002) Real-time monitoring of vegetation biomass with NOAA-AVHRR in Etosha National Park, Namibia, for fire risk assessment. Int J Remote Sens 23:71-89

Saugier B, Roy J, Mooney HA (2001) Estimations of global terrestrial productivity: converging towards a single number? In: Roy J, Saugier B, Mooney HA (eds) Terrestrial global productivity. Academic Press, San Diego, pp 543-557

Seefeldt SS, Booth DT (2006) Measuring plant cover in sagebrush steppe rangelands: a comparison of methods. J Environ Manag 37:703-711

Shamsutdinov NZ, Shamsutdinov ZSh (2008) Biotic melioration of saline-saltish soils using halophytes. Aridnye Ekosist 14(35-36): 18-33

Sivanpillai R, Booth DT (2008) Characterizing rangeland vegetation using landsat and 1-mm VLSA data in central Wyoming (USA). Agrofor Syst 73:55-64

Smith MO, Ustin SL, Adams JB, Gillespie AR (1990) Vegetation in deserts: I. A regional measure of abundance from multispectral images. Remote Sens Environ 31:1-26

Steven MD, Malthus TJ, Baret F, Xu H, Chopping MJ (2003) Intercalibration of vegetation indices from different sensor systems. Remote Sens Environ 88(4):412-422

Stoddard LA, Smith AD (1943) Rangeland management. McGraw Hill Book Co., Inc., New York

Sykes JM, Horrill AD, Mountford MD (1983) Use of visual cover assessments as quantitative estimators of some British woodland taxa. J Ecol 71:437-450 
Tarhouni M, Ben Salem F, Tlili A, Ouled Belgacem A, Neffati M, Louhaichi M (2016) Measurement of the aboveground biomass of some rangeland species using a digital nondestructive technique. Bot Lett 163(3):281-287

Tucker CJ (1978) Comparison of satellite sensor bands for vegetation monitoring. Photogram Eng Remote Sens 44:1369-1380

Tucker CJ (1980) A critical review of remote sensing and other methods for nondestructive estimating of standing crop biomass. Grass Forage Sci 35:177-182

Tucker CJ, Vanpraet C, Boerwinkel E, Gaston A (1983) Satellite remote-sensing of total dry-matter production in the Senegalese sahel. Remote Sens Environ 13(6):461-474

Walker DJ, Lutts S, Sánchez-García M, Correal E (2014) Atriplex halimus L.: its biology and uses. J Arid Environ 100-101:111-121
Williams J, Eric W, Seabloom A, Slayback D, Stoms DM, Viersm JH (2005) Anthropogenic impacts upon plant species richness and net primary productivity in California. Ecol Lett 8:127-137

Winter K (1981) C4 plants of high biomass in arid regions of Asia-occurrence of $\mathrm{C} 4$ photosynthesis in Chenopodiaceae and Polygonaceae from the Middle East and USSR. Oecologia 48(1):100-106

Zhang C, Kovacs JM (2012) The application of small unmanned aerial systems for precision agriculture: a review. Precision Agric 13:693-712 